\title{
A Common Database for Clients and Its Effect on Loan Default in Microfinance Bank Operations: An Outlook of Microfinance Banks in Yola, Adamawa State, Nigeria
}

\author{
Shuaib Jalal-Eddeen ${ }^{1}$, Muawiya Saleh ${ }^{2}$, Fadimatu Jalal-Eddeen ${ }^{3}$ \\ ${ }^{1}$ School of Business \& Entrepreneurship, American University of Nigeria, Yola, Nigeria \\ ${ }^{2}$ School of Arts \& Science, American University of Nigeria, Yola, Nigeria \\ ${ }^{3}$ College of Continuing Education, Adamawa State Polytechnic, Jimeta-Yola, Nigeria \\ Email: *shuaibu.jalaludeen@aun.edu.ng
}

How to cite this paper: Jalal-Eddeen, S., Saleh, M. and Jalal-Eddeen, F. (2019) A Common Database for Clients and Its Effect on Loan Default in Microfinance Bank Operations: An Outlook of Microfinance Banks in Yola, Adamawa State, Nigeria. Open Access Library Journal, 6: e5913.

https://doi.org/10.4236/oalib.1105913

Received: November 11, 2019

Accepted: November 30, 2019

Published: December 3, 2019

Copyright $\odot 2019$ by author(s) and Open Access Library Inc.

This work is licensed under the Creative Commons Attribution International License (CC BY 4.0).

http://creativecommons.org/licenses/by/4.0/

\begin{abstract}
Background: In their quest to address poverty and uneven income and wealth distribution often attributed to low economic growth performance and low labour returns amongst others, the governments of the developing countries through their respective central banks came up with the microfinance policies. In Nigeria, the central bank came up with a policy in 2004, which aims to give micro, small and medium enterprises access to informal financial services to boost their capacity towards economic growth and development. While this policy has reduced the level of poverty among the low-income populace, the operations of the microfinance institutions are receiving increasing threats from the beneficiaries, especially loan default, which is often as a result to multiple borrowing. Methods: A cross-sectional study using a mixed method approach was adopted for the study. The questionnaires were distributed to eligible persons and the responses analysed using SPSS version 24 and a simple Microsoft Excel. The respondents were clients from three randomly selected microfinance institutions in Yola, Adamawa State, Nigeria. Results: The outcome of this study has shown that while about $66 \%$ multiple borrowing incidences from various microfinance institutions were very high, $91.43 \%$ and $77.14 \%$ of the respondents believed that multiple borrowing and loan default, respectively, could be prevented through the use of a common database. Conclusion: It is recommended that microfinance banks and institutions should invest in implementing a common database for managing client requirements and minimizing concurrent borrowing and loan defaults.
\end{abstract}




\section{Subject Areas}

Business Analysis

\section{Keywords}

Common Client Database, Multiple Borrowing, Microfinance Institutions, Loan Default, Targeted Sensitization, Adamawa State, Nigeria

\section{Introduction}

In their quest to address poverty and uneven income and wealth distribution which is often attributed to low economic growth performance and low labour returns amongst others, the governments of the developing countries through their respective central banks came up with the microfinance policies. In an attempt to address this problem, Nigeria government made frantic efforts towards encouraging entrepreneurship within the populace with programs such as YOUWIN [1] which targeted the youth to promote entrepreneurship among them to solve the problem of unemployment. The other programmes put in place by the government that aims to reduce the rising poverty rates, and which arguably could be regarded as a failure as there was no visible improvement in the lives of the populace, included a subsidy reinvestment program tagged as SURE-P, initiatives channelled through the Bank of Industry, the National Economic Reconstruction Fund (NERFUND) and the Poverty Alleviation Program (PAP) [2].

In a UNICEF report [3] on the developing economies, majority of the population lives below the recommended United Nations poverty line, with $70.8 \%$ surviving on barely $\$ 1$ per day and $92.4 \%$ on $\$ 2$ per day. This alarming situation requires a concerted effort by governments across the globe, hence the declaration of a state of emergency by the United Nations which resulted in the birth of the millennium development goals (MDGs) that aimed at eradicating poverty before the year 2015. While a lot of progress has been achieved across the developing countries, still more needs to be done for wealth and income to be distributed to the less privileged within the country to achieve the required economic and social growth.

In Nigeria, the central bank came up with a policy in 2004 which aims to give micro, small and medium enterprises access to informal financial services to boost their capacity towards economic growth and development [4]. While this policy has reduced the level of poverty among the low-income populace, the operations of the microfinance institutions are receiving increasing threats from the beneficiaries, especially loan default, which is often attributed to multiple borrowing. The establishment of microfinance banks and institutions has gone a long way in curtailing the problem of poverty, with such models like the Grameen Foundation and Fundacion Paraguaya. 
While the origins of microfinance dated to the biblical era where people practised borrowing and savings, the modern microfinance started getting traction circa 1970 when Muhammed Yunus, the foremost professor of economics and Nobel Prize winner introduced his Grameen Bank concept of microfinance. This strategy has been cloned by countries worldwide after the realization of the fact that it is a handy tool that can be used to reduce high poverty rates in the world [5]. This is not to say that there hasn't been any form of formal lending practices going on over the years before his discovery, although most of them were rather political than for a social cause. There are for instance the financial experiments, which led to the birth of cooperative societies in Europe in the mid 19th century [6] and the then assistance of Latin Americans by left-wing US politicians to challenge the United States' imposition of capitalism on them, in the form of loans and reliefs [7].

There have been other personalities too who have contributed to the development of microfinance institutions in the 1970s, with them focusing more on less developed countries. We have such personalities as John Hatch, who developed the FINCA Village banking method of administering loans to Peru farmers and the Women's World Banking concept of giving out loans to low-income earning women. It is also worthy to note the works of Akhtar Khan of the Tameer Bank and SEWA's Ela Blatt who have both significantly contributed to the growth of microfinance over the late last century. The whole microfinance concept has since then slightly shifted from an entity that serves the needs of the poor to a modern-day commercialized body [8] (Figure 1).

Nigeria, once considered among the top five oil-producing nations across the globe [9] and with a GDP per capita of approximately $\$ 1000$ and GNI per capita of 5710 [10], its indicators of development in terms of poverty, gross national income and even distribution of resources are somewhat not encouraging. The growing gap between the rich and the poor is alarming, hence the need for the government to put in place policies that would ensure a fair distribution of wealth among the populace. It is interesting to note that, in the developing countries, some of the reasons for poverty and uneven income and wealth distribution are linked to low economic growth performance and low labour returns [11].

In Nigeria, the record has shown that the majority of the populace when they
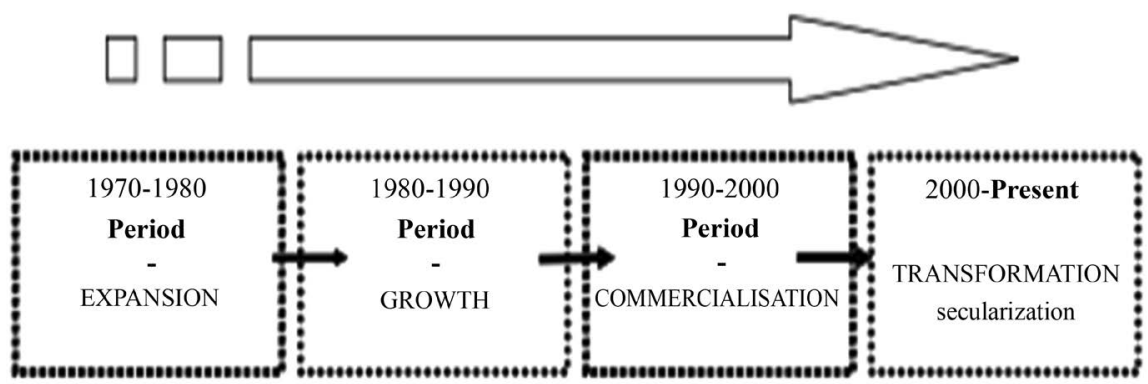

Figure 1. Depicting the various stages of microfinance development (Srnec, 2007). 
engage in one labour activity or the other do not get the required compensation needed to support themselves. As a result of the ineffectiveness of policies by governments of the developing countries to curtail these problems, the international community encouraged the developing economies to adopt the use of microfinance banks and institutions to address these challenges [12], as evidenced by the Grameen Foundation and FundacionParaguaya. The central bank, in Nigeria, came up with the microfinance policy in 2004 and the sole purpose was to give micro, small and medium enterprises access to informal financial services to boost their capacity towards economic growth and development [4]. It was also the objective of a subsequent microfinance policy enacted in 2005 to quickly provide credit facilities and small loans to low-income earners. The policy has gone a long way in springing up microfinance banks and institutions across the country to provide the said services.

Although there have been various personalities who have contributed to the development of microfinance institutions in the 1970s focusing more on less developed countries, modern microfinance started getting traction circa 1970 when Muhammed Yunus, the foremost professor of economics and Nobel Prize winner introduced his Grameen Bank concept of microfinance [5]. As observed in other studies, effective sensitization program to clients would significantly prevent factors such as client poaching, loan recycling, insufficient funds and loan pushing, which results in multiple borrowing [13]. It is also expected that targeted sensitization of the clients and the effective implementation of the common client database by the microfinance institutions would help in addressing the issue of multiple borrowing and loan default by clients. As highlighted by the conceptual framework for this study (Figure 2), multiple borrowing results in loan default and vice-versa. However, when issues of loan defaulting or multiple borrowing come up, the microfinance institutions are expected to walk the clients back up through the sensitization process [13].

\section{Method}

In this study, 150 questionnaires were distributed among the eligible persons

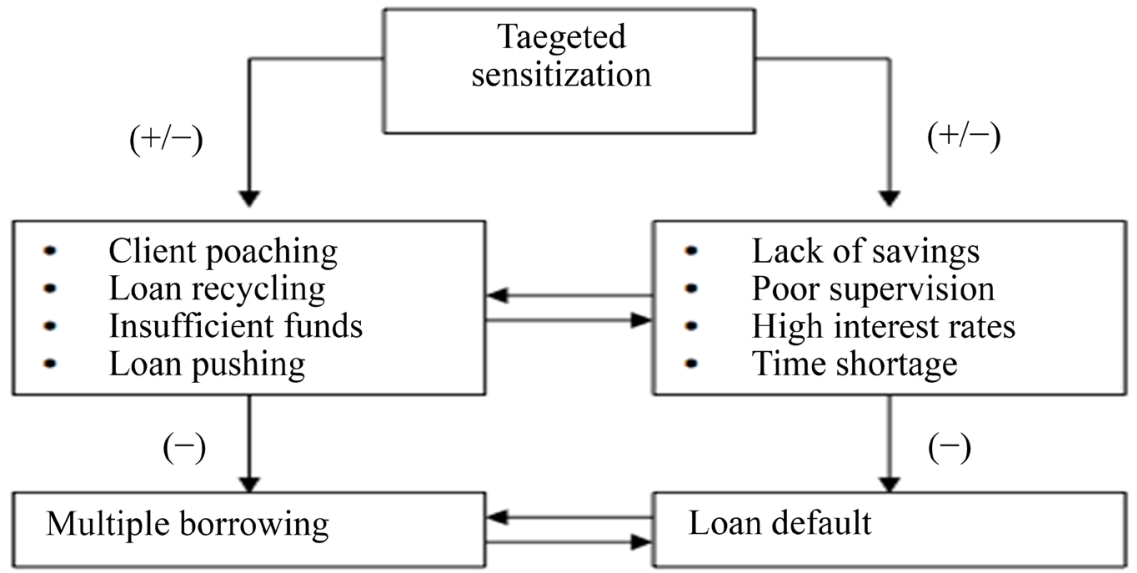

Figure 2. The conceptual framework for the study. 
selected from three microfinance institutions in Yola, the state capital of Adamawa State, northeastern Nigeria; Buyu Foundation, Hududullah Microfinance Institution, Standard Microfinance Bank. The idea of establishing a common database to curb default was shared with the clients, and their opinions with regards to that were presented. The research used a mixed-method descriptive research design and cross-sectional survey approach to collect the responses. This research design is the foundation of every research work as it helps us know how to go about looking for information. The reason for this mixture of approach is to be able to adequately describe the thoughts, feedbacks and inputs of the various respondents. Similarly, this survey method is the most suitable with descriptive research design as the questionnaires were used to draw information from respondents. However, in a case where a respondent lacks western education, an oral interview was conducted.

The centre for this study, Yola, is the state capital of Adamawa state and has an estimated population of at least 400,000 [13]. The majority (about $80 \%$ ) of the people are living below the poverty line of $\$ 2$ per day [14] with approximately 40,000 adults $(10 \%)$ patronising the microfinance banks available in the state capital (i.e. under 5000). Using SPSS version 24 and Microsoft Excel, the collated data were analysed to look at the influencers of multiple borrowing in the microfinance institutions that leads to loan default.

The objective of this research is to determine if access to a shared database of microfinance bank clients has any effect on loan default. The significance of the study is that it will help in microfinance banks to develop a robust central database that could go a long way in addressing the issues of multiple borrowing and loan defaulting.

The research question for this research is:

RQ: Does targeted sensitisation have any effect on loan default reduction?

The hypotheses of the proposed research, after reviewing of relevant literature and the problem statement, are that:

H0-Microfinance banks accessing a common database of clients (showing selected borrowing information) does not reduce loan default rates.

H1-Microfinance banks accessing a common database of clients (showing selected borrowing information) reduces loan default.

The independent and dependent variables are "common database" and "loan default rates" respectively. The sample size of 96 was calculating SPSS version 24 (assuming a design effect of 1, a confidence level of $95 \%$, an alpha of $5 \%$, and an estimated prevalence of 50\%). The questionnaire had two sections; section A was on the demography of the respondents, and section B looked at the factors and effects of multiple borrowing looking, targeted sensitization, and common database access. Over 150 questionnaires were administered in Yola and Jimeta, but only a total of 70 valid responses were collated. The actual sampling method used was a non-probability sampling somewhat convenient because of the limited time available to conduct the research. The clients were hard to track as most of them rarely visited the bank premises except for when they encounter 
problems or during repayment periods, hence the main reason for collating 70 valid responses.

\section{Results and Discussions}

Out of the $70(46.7 \%)$ collated responses, $50.00 \%$ were within the age range of 36 - 45 years; $45.71 \%$ attained primary school, and males are the highest borrowers (52.86\%).

Table 1 tries to describe the attitudes of respondents towards the idea of developing a common database. According to the table, $47.14 \%$ of respondents believed developing a common database for better service delivery was a good idea, $45.71 \%$ were indifferent about it and $7.14 \%$ believed it was a bad idea. Results from the table show that most respondents believed it would be a good idea.

According to Table 2, 77.14\% of respondents believed loan default could be prevented through the use of a common database and $22.86 \%$ did not believe it could. Results from the table show that most of the respondents were in support of using common databases to prevent default.

According to Table 3, 91.43\% of respondents believed multiple borrowing could be prevented through the use of common databases and $8.57 \%$ believed it could not. Results from the table also show that most of the respondents believed it could be prevented.

Table 4 shows a crosstabs analysis between the level of education of respondents and their willingness to pay on time. The analysis shows that the relationship between the two is somewhat insignificant at a 95\% level of confidence ( $\mathrm{p}$ value $<0.301)$. This means that respondents' willingness to pay on time had nothing to do with their level of education.

Table 1. Showing attitude of clients towards developing a common database for better service.

(a)

\begin{tabular}{cccccc}
\hline Value Label & Value & Frequency & Percent & Valid Percent & Cum Percent \\
\hline I think it would be good & 1 & 33 & 47.14 & 47.14 & 47.14 \\
It does not bother me & 2 & 32 & 45.71 & 45.71 & 92.86 \\
I think it would be bad & 3 & 5 & 7.14 & 7.14 & 100.00 \\
Total & & 70 & 100.0 & 100.0 & \\
\hline
\end{tabular}

(b)

\begin{tabular}{ccc}
\hline$N$ & Valid & 70 \\
\hline & Missing & 0 \\
\hline Mean & 1.60 \\
Mode & 1.00 \\
Std Dev & 0.62 \\
Minimum & 1.00 \\
Maximum & 3.00 \\
\hline
\end{tabular}


Table 2. Showing preventing loan default through the use of common databases.

(a)

\begin{tabular}{|c|c|c|c|c|c|}
\hline Value Label & Value & Frequency & Percent & Valid Percent & Cum Percent \\
\hline Yes & 1 & 54 & 77.14 & 77.14 & 77.14 \\
\hline No & 2 & 16 & 22.86 & 22.86 & 100.00 \\
\hline \multicolumn{2}{|l|}{ Total } & 70 & 100.0 & 100.0 & \\
\hline
\end{tabular}

(b)

\begin{tabular}{ccc}
\hline$N$ & Valid & 70 \\
\hline & Missing & 0 \\
\hline Mean & 1.23 \\
Mode & 1.00 \\
Std Dev & 0.42 \\
Minimum & 1.00 \\
Maximum & 2.00 \\
\hline
\end{tabular}

Table 3. Showing preventing multiple borrowing with common databases.

(a)

\begin{tabular}{|c|c|c|c|c|c|}
\hline Value Label & Value & Frequency & Percent & Valid Percent & Cum Percent \\
\hline Yes & 1 & 64 & 91.43 & 91.43 & 91.43 \\
\hline No & 2 & 6 & 8.57 & 8.57 & 100.00 \\
\hline \multicolumn{2}{|l|}{ Total } & 70 & 100.0 & 100.0 & \\
\hline
\end{tabular}

(b)

\begin{tabular}{ccc}
\hline$N$ & Valid & 70 \\
\hline Mean & Missing & 0 \\
Mode & 1.09 \\
Std Dev & 1.00 \\
Minimum & 0.28 \\
Maximum & 1.00 \\
\hline
\end{tabular}

Table 4. Showing Always timely repayments Versus Level of education.

(a)

\begin{tabular}{ccccccc}
\hline \multicolumn{7}{c}{ Level of Education } \\
\hline $\begin{array}{c}\text { Always Timely } \\
\text { Repayments }\end{array}$ & None & $\begin{array}{c}\text { Primary } \\
\text { school }\end{array}$ & $\begin{array}{c}\text { Secondary } \\
\text { school }\end{array}$ & Polytechnicl Uni. & Other & Total \\
\hline Yes & 5.00 & 17.00 & 6.00 & 7.00 & 0.00 & 35.00 \\
& $14.29 \%$ & $48.57 \%$ & $17.14 \%$ & $20.00 \%$ & $0.00 \%$ & $100.00 \%$ \\
& $35.71 \%$ & $53.13 \%$ & $50.00 \%$ & $70.00 \%$ & $0.00 \%$ & $50.00 \%$ \\
& $7.14 \%$ & $24.29 \%$ & $8.57 \%$ & $10.00 \%$ & $0.00 \%$ & $50.00 \%$ \\
\hline
\end{tabular}




\begin{tabular}{ccccccc} 
Continued & \multicolumn{7}{c}{} & & & & \\
\hline No & 9.00 & 15.00 & 6.00 & 3.00 & 2.00 & 35.00 \\
& $25.71 \%$ & $42.86 \%$ & $17.14 \%$ & $8.57 \%$ & $5.71 \%$ & $100.00 \%$ \\
& $64.29 \%$ & $46.88 \%$ & $50.00 \%$ & $30.00 \%$ & $100.00 \%$ & $50.00 \%$ \\
& $12.86 \%$ & $21.43 \%$ & $8.57 \%$ & $4.29 \%$ & $2.86 \%$ & $50.00 \%$ \\
& 14.00 & 32.00 & 12.00 & 10.00 & 2.00 & 70.00 \\
& $20.00 \%$ & $45.71 \%$ & $17.14 \%$ & $14.29 \%$ & $2.86 \%$ & $100.00 \%$ \\
& $100.00 \%$ & $100.00 \%$ & $100.00 \%$ & $100.00 \%$ & $100.00 \%$ & $100.00 \%$ \\
& $20.00 \%$ & $45.71 \%$ & $17.14 \%$ & $14.29 \%$ & $2.86 \%$ & $100.00 \%$ \\
\hline
\end{tabular}

(b)

\begin{tabular}{cccc}
\hline Chi-square tests & & & \\
\hline Statistic & Value & $d f$ & Asymp. Sig. (2-tailed) \\
\hline Pearson Chi-Square & 4.87 & 4 & 0.301 \\
Likelihood Ratio & 5.70 & 4 & 0.223 \\
Linear-by-Linear Association & 0.47 & 1 & 0.494 \\
Nof Valid Cases & 70 & & \\
\hline
\end{tabular}

Table 5 shows a crosstabs analysis between number of late repayment times and level of education of respondents. Results from the analysis show that the relationship between the two is somewhat insignificant ( $\mathrm{p}$ value $<0.362$ ). In other words, the level of education of respondents did not influence the number of times they paid back loans.

Table 6 shows a crosstabs analysis between the variables "attitude to common database" and "level of education." Results from the analysis show that the relationship between the two is somewhat significant ( $p$ value $<0.49$ ). This means that education has a significant impact on the attitudes of respondents with regards to developing a common database. According to findings from the research, majority of the respondents $(47.14 \%)$ believed that developing a common database for better facilitation of loan requirements is a good idea and 77.14\% believed loan default could be prevented through the use of common databases. In addition, $91.43 \%$ believed multiple borrowing could be prevented via the use of common databases. This further restates the fact that microfinance banks accessing common database of clients reduces loan default rates hence the null hypothesis is rejected.

Table 7 shows a crosstabs analysis between attitude to concurrent borrowing and level of education. Results from the table show that the relationship between the two is somewhat insignificant ( $\mathrm{p}$-value $<0.375$ ). This means that the level of education of respondents has nothing to do with their attitude towards concurrent borrowing.

As observed by Shuaib et al. [14], microfinance banks and institutions continue to be plagued with a series of problems, the biggest of which is loan defaulting 
Table 5. Showing number of late repayment times Versus Level of education.

(a)

\begin{tabular}{|c|c|c|c|c|c|c|}
\hline \multirow[b]{2}{*}{$\begin{array}{l}\text { No. of Late } \\
\text { Repayments }\end{array}$} & \multicolumn{5}{|c|}{ Level of Education } & \multirow[b]{2}{*}{ Total } \\
\hline & None & $\begin{array}{c}\text { Primary } \\
\text { school }\end{array}$ & $\begin{array}{c}\text { Secondary } \\
\text { school }\end{array}$ & Polytechnicl Uni. & Other & \\
\hline \multirow[t]{4}{*}{1 time only } & 0.00 & 1.00 & 1.00 & 2.00 & 1.00 & 5.00 \\
\hline & $0.00 \%$ & $20.00 \%$ & $20.00 \%$ & $40.00 \%$ & $20.00 \%$ & $100.00 \%$ \\
\hline & $0.00 \%$ & $6.67 \%$ & $16.67 \%$ & $66.67 \%$ & $50.00 \%$ & $14.29 \%$ \\
\hline & $0.00 \%$ & $2.86 \%$ & $2.86 \%$ & $5.71 \%$ & $2.86 \%$ & $14.29 \%$ \\
\hline \multirow[t]{4}{*}{2 times only } & 4.00 & 7.00 & 3.00 & 1.00 & 1.00 & 16.00 \\
\hline & $25.00 \%$ & $43.75 \%$ & $18.75 \%$ & $6.25 \%$ & $6.25 \%$ & $100.00 \%$ \\
\hline & $44.44 \%$ & $46.67 \%$ & $50.00 \%$ & $33.33 \%$ & $50.00 \%$ & $45.71 \%$ \\
\hline & $11.43 \%$ & $20.00 \%$ & $8.57 \%$ & $2.86 \%$ & $2.86 \%$ & $45.71 \%$ \\
\hline \multirow[t]{4}{*}{3 to 5 times } & 4.00 & 5.00 & 2.00 & 0.00 & 0.00 & 11.00 \\
\hline & $36.36 \%$ & $45.45 \%$ & $18.18 \%$ & $0.00 \%$ & $0.00 \%$ & $100.00 \%$ \\
\hline & $44.44 \%$ & $33.33 \%$ & $33.33 \%$ & $0.00 \%$ & $0.00 \%$ & $31.43 \%$ \\
\hline & $11.43 \%$ & $14.29 \%$ & $5.71 \%$ & $0.00 \%$ & $0.00 \%$ & $31.43 \%$ \\
\hline \multirow[t]{4}{*}{6 to 10 times } & 1.00 & 2.00 & 0.00 & 0.00 & 0.00 & 3.00 \\
\hline & $33.33 \%$ & $66.67 \%$ & $0.00 \%$ & $0.00 \%$ & $0.00 \%$ & $100.00 \%$ \\
\hline & $11.11 \%$ & $13.33 \%$ & $0.00 \%$ & $0.00 \%$ & $0.00 \%$ & $8.57 \%$ \\
\hline & $2.86 \%$ & $5.71 \%$ & $0.00 \%$ & $0.00 \%$ & $0.00 \%$ & $8.57 \%$ \\
\hline \multirow[t]{4}{*}{ Total } & 9.00 & 15.00 & 6.00 & 3.00 & 2.00 & 35.00 \\
\hline & $25.71 \%$ & $42.86 \%$ & $17.14 \%$ & $8.57 \%$ & $5.71 \%$ & $100.00 \%$ \\
\hline & $100.00 \%$ & $100.00 \%$ & $100.00 \%$ & $100.00 \%$ & $100.00 \%$ & $100.00 \%$ \\
\hline & $25.71 \%$ & $42.86 \%$ & $17.14 \%$ & $8.57 \%$ & $5.71 \%$ & $100.00 \%$ \\
\hline
\end{tabular}

(b)

\begin{tabular}{cccc}
\hline Chi-square tests & & & \\
\hline Statistic & Value & $d f$ & Asymp. Sig. (2-tailed) \\
\hline Pearson Chi-Square & 13.09 & 12 & 0.362 \\
Likelihood Ratio & 13.48 & 12 & 0.335 \\
Linear-by-Linear Association & 7.59 & 1 & 0.006 \\
Nof Valid Cases & 35 & & \\
\hline
\end{tabular}

Table 6. Showing Attitude to common database Versus Level of education.

(a)

\begin{tabular}{ccccccc}
\hline \multicolumn{7}{c}{ Level of Education } \\
\hline $\begin{array}{c}\text { Attitude To Common } \\
\text { Database }\end{array}$ & None & $\begin{array}{c}\text { Primary } \\
\text { school }\end{array}$ & $\begin{array}{c}\text { Secondary } \\
\text { school }\end{array}$ & Polytechnicl Uni. & Other & Total \\
\hline I think it would be good & 3.00 & 13.00 & 7.00 & 8.00 & 2.00 & 33.00 \\
& $9.09 \%$ & $39.39 \%$ & $21.21 \%$ & $24.24 \%$ & $6.06 \%$ & $100.00 \%$ \\
& $21.43 \%$ & $40.63 \%$ & $58.33 \%$ & $80.00 \%$ & $100.00 \%$ & $47.14 \%$ \\
& $4.29 \%$ & $18.57 \%$ & $10.00 \%$ & $11.43 \%$ & $2.86 \%$ & $47.14 \%$ \\
\hline
\end{tabular}




\section{Continued}

\begin{tabular}{ccccccc}
\hline It does not bother me & 8.00 & 18.00 & 4.00 & 2.00 & 0.00 & 32.00 \\
& $25.00 \%$ & $56.25 \%$ & $12.50 \%$ & $6.25 \%$ & $0.00 \%$ & $100.00 \%$ \\
& $57.14 \%$ & $56.25 \%$ & $33.33 \%$ & $20.00 \%$ & $0.00 \%$ & $45.71 \%$ \\
& $11.43 \%$ & $25.71 \%$ & $5.71 \%$ & $2.86 \%$ & $0.00 \%$ & $45.71 \%$ \\
\multirow{2}{*}{ I think it would be bad } & 3.00 & 1.00 & 1.00 & 0.00 & 0.00 & 5.00 \\
& $60.00 \%$ & $20.00 \%$ & $20.00 \%$ & $0.00 \%$ & $0.00 \%$ & $100.00 \%$ \\
& $21.43 \%$ & $3.13 \%$ & $8.33 \%$ & $0.00 \%$ & $0.00 \%$ & $7.14 \%$ \\
& $4.29 \%$ & $1.43 \%$ & $1.43 \%$ & $0.00 \%$ & $0.00 \%$ & $7.14 \%$ \\
& 14.00 & 32.00 & 12.00 & 10.00 & 2.00 & 70.00 \\
& $20.00 \%$ & $45.71 \%$ & $17.14 \%$ & $14.29 \%$ & $2.86 \%$ & $100.00 \%$ \\
& $100.00 \%$ & $100.00 \%$ & $100.00 \%$ & $100.00 \%$ & $100.00 \%$ & $100.00 \%$ \\
& $20.00 \%$ & $45.71 \%$ & $17.14 \%$ & $14.29 \%$ & $2.86 \%$ & $100.00 \%$ \\
\hline
\end{tabular}

(b)

\begin{tabular}{cccc}
\hline Chi-square tests & & & \\
\hline Statistic & Value & $d f$ & Asymp. Sig. (2-tailed) \\
\hline Pearson Chi-Square & 15.59 & 8 & 0.049 \\
Likelihood Ratio & 16.30 & 8 & 0.038 \\
Linear-by-Linear Association & 11.50 & 1 & 0.001 \\
Nof Valid Cases & 70 & & \\
\hline
\end{tabular}

Table 7. Showing Attitude to concurrent borrowing Versus Level of education.

(a)

\begin{tabular}{ccccccc}
\hline \multicolumn{7}{c}{ Level of Education } \\
\hline $\begin{array}{c}\text { Attitude To } \\
\text { Concurrent Borrowing }\end{array}$ & None & $\begin{array}{c}\text { Primary } \\
\text { school }\end{array}$ & $\begin{array}{c}\text { Secondary } \\
\text { school }\end{array}$ & Polytechnicl Uni. & Other & Total \\
\hline I think it is a good & 3.00 & 6.00 & 0.00 & 2.00 & 0.00 & 11.00 \\
& $27.27 \%$ & $54.55 \%$ & $0.00 \%$ & $18.18 \%$ & $0.00 \%$ & $100.00 \%$ \\
& $21.43 \%$ & $18.75 \%$ & $0.00 \%$ & $20.00 \%$ & $0.00 \%$ & $15.71 \%$ \\
& $4.29 \%$ & $8.57 \%$ & $0.00 \%$ & $2.86 \%$ & $0.00 \%$ & $15.71 \%$ \\
It does not bother me & 7.00 & 16.00 & 5.00 & 3.00 & 0.00 & 31.00 \\
& $22.58 \%$ & $51.61 \%$ & $16.13 \%$ & $9.68 \%$ & $0.00 \%$ & $100.00 \%$ \\
& $50.00 \%$ & $50.00 \%$ & $41.67 \%$ & $30.00 \%$ & $0.00 \%$ & $44.29 \%$ \\
& $10.00 \%$ & $22.86 \%$ & $7.14 \%$ & $4.29 \%$ & $0.00 \%$ & $44.29 \%$ \\
& 4.00 & 10.00 & 7.00 & 5.00 & 2.00 & 28.00 \\
& $14.29 \%$ & $35.71 \%$ & $25.00 \%$ & $17.86 \%$ & $7.14 \%$ & $100.00 \%$ \\
& $28.57 \%$ & $31.25 \%$ & $58.33 \%$ & $50.00 \%$ & $100.00 \%$ & $40.00 \%$ \\
& $5.71 \%$ & $14.29 \%$ & $10.00 \%$ & $7.14 \%$ & $2.86 \%$ & $40.00 \%$ \\
& 14.00 & 32.00 & 12.00 & 10.00 & 2.00 & 70.00 \\
& $20.00 \%$ & $45.71 \%$ & $17.14 \%$ & $14.29 \%$ & $2.86 \%$ & $100.00 \%$ \\
& $100.00 \%$ & $100.00 \%$ & $100.00 \%$ & $100.00 \%$ & $100.00 \%$ & $100.00 \%$ \\
& $20.00 \%$ & $45.71 \%$ & $17.14 \%$ & $14.29 \%$ & $2.86 \%$ & $100.00 \%$ \\
\hline
\end{tabular}


(b)

\begin{tabular}{cccc}
\hline Chi-square tests. & & & \\
\hline Statistic & Value & $d f$ & Asymp. Sig. (2-tailed) \\
\hline Pearson Chi-Square & 8.63 & 8 & 0.375 \\
Likelihood Ratio & 11.13 & 8 & 0.194 \\
Linear-by-Linear Association & 3.87 & 1 & 0.049 \\
Nof Valid Cases & 70 & & \\
\hline
\end{tabular}

whereby clients do not fulfill payment of their credit facilities when due. They do so for a number of reasons, one of which is multiple borrowing and as a result, that hinders on the core objective of the bank, which is to distribute income amongst the lower-class population. Similarly, Shuaib et al. underscored the importance of targeted sensitization as an important strategy in reducing loan defaults in microfinance operations.

\section{Conclusions}

The outcome of this study shows that most respondents believed if a database could be properly developed, deployed and maintained by a secure, trusted, and independent body, it could go a long way in addressing the issues of multiple borrowing and loan defaulting.

The recommendation here is that microfinance banks and institutions should invest in implementing a common database for managing client requirements and minimizing concurrent borrowing and loan defaults. However, this initiative should be combined with appropriate sensitization programs as a strategy in reducing loan defaults.

\section{Limitations}

The study was limited by the fact there were a limited number of responses obtained as the clients were hard to track down. However, the limited responses should be viewed as an opportunity to uncover deeper meaning in the responses collated and to conduct further studies in that regard. Also, there was an issue with the reliability of the responses because some of the respondents deliberately withheld information for fear that it might be shared with the microfinance banks.

\section{Acknowledgements}

We acknowledge with gratitude the cooperation of the microfinance houses where this research was carried out.

\section{Funding}

We declare that no funding is received from any source for this research.

\section{Conflicts of Interest}

We declare that there is no any potential conflict of interest or royalty associated 
with the manuscript.

\section{References}

[1] Andrews, J. and Emejo, J. (2014) Jonathan Launches \$50m Venture Capital Fund, Fourth Phase of You Win.

http://businessnews.com.ng/2014/11/19/jonathan-launches-50m-venture-capital-fu nd-fourth-phase-youwin/

[2] World Bank (2016) Nigeria Subsidy Reinvestment and Empowerment Programme (SURE-P): Maternal and Child Health Initiative.

https://www.worldbank.org/en/programs/sief-trust-fund/brief/nigeria-subsidy-rein vestment-and-empowerment-programme-sure-p

[3] UNICEF (2016) UNICEF Nigeria.

http://www.unicef.org/wcaro/Countries_1320.html

[4] Nwaogazi, A. (2010) Are Some MFBs Micro-Finance or Misfeasance Institutions. Daily Trust. https://allafrica.com/stories/201010140480.html

[5] Bateman, M. (2014) The Rise and Fall of Muhammad Yunus and the Micro Credit Model.

http://www.microfinancegateway.org/sites/default/files/mfg-en-paper-the-rise-andfall-of-muhammad-yunus-and-the-microcredit-model-jan-2014.pdf https://doi.org/10.2139/ssrn.2385190

[6] Birchall, J. (1994) Coop: The People's Business. Manchester University Press, Manchester.

[7] Nye, J. (1990) Bound to Lead: The Changing Nature of American Power. Basic Books, New York.

[8] Srnec, K. (2007) Microfinance-Tool for Poverty Alleviation in the Less Developed Countries. Habilitation Thesis, Institute of Tropics and Subtropics, Czech University of Life Sciences, Prague.

[9] Kazi, M.H. and Leonard, J.E. (2012) Microfinance, Poverty and Youth Unemployment of Nigeria: A Review. Global Journal of Human Social Science, Sociology, Economics \& Political Science, 12, 45-59. https://globaljournals.org/GJHSS_Volume12/6-Microfinance-Poverty-and-Youth.pdf

[10] Trading Economics (2016) Nigeria GDP. http://www.tradingeconomics.com/nigeria/gdp

[11] Olowa, W. (2012) Concept, Measurement and Causes of Poverty: Nigeria in Perspective. American Journal of Economics, 2, 25-36. https://doi.org/10.5923/j.economics.20120201.04

[12] Okunmadewa, F. (1998) Domestic and International Response to Poverty Alleviation in Nigeria. Proceedings of the 7 th Annual Conference of the Zonal Research Units, Research Department of CBN, Makurdi.

[13] Mpogole, H., Mwaungulu, I., Mlasu, S. and Lubawa, G. (2012) Multiple Borrowing and Loan Repayment: A Study of Microfinance Clients at Iringa, Tanzania. Global Journal of Management and Business Research, 12, 96-102.

https://globaljournals.org/GJMBR_Volume12/10-Multiple-Borrowing-and-Loan-Re payment.pdf

[14] Jalaludeen, S., Che, F. and Jalal-Eddeen, F. (2018) Targeted Sensitization as a Strategy to Reducing Loan Default in Microfinance Bank Operations in Yola, Adamawa State, Nigeria. Open Access Library Journal, 5, e4275.

https://doi.org/10.4236/oalib.1104275 